\title{
AKUNTABILITAS TERHADAP PEMBAYARAN PAJAK BUMI DAN BANGUNAN DI DESA DAMAI KECAMATAN WATANG SIDENRENG KABUPATEN SIDENRENG RAPPANG
}

\author{
1)Rina Rukmanti, ${ }^{2)}$ Adam Latif, ${ }^{3)}$ Akhyaruddin Hakim \\ Fakultas IImu Sosial Dan IImu Politik Universitas Muhammadiyah Sidenreng Rappang \\ rinarukmanti7298@gmail.com
}

\begin{abstract}
Abstrak
Tingkat Kualitas Akuntabilitas terhadap Pembayaran Pajak Bumi dan Bangunan di Desa Damai Kecamatan Watang Sidenreng Kabupaten Sidenreng Rappang, dan untuk mengetahui faktor-faktor yang mempengaruhi Tingkat Kesadaran Masyarakat dalam Membayar Pajak Bumi dan Bangunan Di Desa Damai Kecamatan Watang Sidenreng Kabupaten Sidenreng Rappang. Populasi dalam penelitian ini adalah 1.486 yang dimana pengambilan Sampel yang digunakan yaitu Probability Sampling dengan teknik teknik sampling acak/random sampling dengan dengan menggunakan rumus Yount $5 \%$ dengan jumlah sampel 74. Penelitian ini menggunakan Metode Deskriptif Kuantitatif. Teknik pengumpulan data yang digunakan melalui Observasi, kuesioner (angket), dokumentasi dan wawancara. Teknik analisis data yang digunakan adalah Statistik Deskriptif, uji kualitas data, uji asumsi klasik dengan menggunakan SPSS 21 dan Skala Likert. Hasil penelitian menunjukkan bahwa akuntabilitas terhadap pembayaran pajak bumi dan bangunan di desa damai kecamatan watang sidenreng di kategorikan "Berpengaruh/signifikan", dari uji ANOVA di dapat $f$ hitung 13.325 keseluruhan berpengaruh/signifikan dan probabilitas jauh dari 0,05. Selanjutnya secara parsial $t$ hitung (3.650) > t tabel (1993) artinya tingkat akuntabilitas berpengaruh/signifikan terhadap Pembayaran Pajak Bumi dan Bangunan di Desa Damai, faktor yang mempengaruhi tingkat kesadaran masyarakat dalam membayar Pajak Bumi Dan Bangunan di Desa Damai Kecamatan Watang Sidenreng Kabupetn Sidenreng Rappang $60,6 \%$ termasuk dalam kategori "baik".
\end{abstract}

Kata Kunci: Akuntabilitas, Pajak Bumi dan Bangunan

\begin{abstract}
The level of accountability forand building tax payments in Damai Village, Watang Sidenreng District, Sidenreng Rappang District, and to find out the factors that influence the level of community awareness in paying land taxes and Buildings in Damai Village, Watang Sidenreng District, Sidenreng Rappang Regency. The population in this study was 1,486 where the sampling used was Probability Sampling with a random sampling technique using aformula of Yount 5\% with a total sample of 74. This study used a Quantitative Descriptive Method. Data collection techniques used through observation, questionnaires (questionnaire), documentation and interviews. The data analysis technique used is Descriptive Statistics, data quality test, classic assumption test using SPSS 21 and Likert Scale. The results showed that accountability for land and building tax payments in the peaceful village of Watang Sidenreng sub-district was categorized as "Influentiall significant", from the ANOVA test it was able to calculate 13,325 overall, influential/ significant and the probability was far from 0.05 . Furthermore partially $t$ arithmetic $(3,650)>t$ table (1993) means that the level of accountability influences / significantly on Land and Building Tax Payments in Damai Village, factors that influence the level of public awareness in paying Land and Building Taxes in Damai Village Watang Sidenreng District Sidenreng Regency Rappang $60.6 \%$ included in the category of "good".
\end{abstract}

Keywords: Accountability, Land and Building Tax

PRAJA $\mid$ Volume 3| Nomor 3| Edisi Oktober 2020 


\section{A. Pendahuluan}

Berdasarkan Pasal 1 UU No.28 Tahun 2007, pajak adalah kontribusi wajib kepada negara oleh orang pribadi atau badan yang bersifat memaksa berdasarkan undang-undang, pajak digunakan untuk keperluan negara supaya menciptakan kemakmuran rakyat sebesar-besarnya. Sumber terbesar dalam pendapatan kas negara adalah bersumber dari pemungutan pajak. Pemungutannya selalu mengalami kendala sekaligus masalah misalnya masalah kepatuhan masyarakat dalam membayar pajak negara. Mulai dari tahun 2010 segala urusan termasuk penarikan iuran terutang PBB diberikan oleh Pemerintah Pusat ke Pemerintah Kota/Kabupaten. Dengan demikian setiap tahunnya Desa diberikan target dalam penerimaan pajak bumi dan bangunan yang selanjutnya akan dikembalikan sesuai presentase kepada Pemerintah Desa Sehingga Pemerintah Desa dianggap sebagai ujung tombak pendapatan daerah karena besar atau kecilnya Pendapatan Daerah pada sektor pajak bumi dan bangunan, yang langsung bergantung pada Pemerintah Desa. Dengan begitu Pemerintah Desa perlu berperan aktif dan berupaya mengoptimalkan penerimaan pajak khususnya PBB.

Pentingnya dana penerimaan PBB terhadap pendapatan yang selanjutnya digunakan untuk pembiayaan dan pembangunan daerah perlu didukung oleh peran aktif serta strategi perangkat desa sebagai stakeholder yang langsung bersentuhan dengan wajib pajak dalam melayani dan memotivasi masyarakat agar taat membayar iuran pajak. Proses pemungutan sering mengalami masalah seperti minimnya kesadaran masyarakat untuk membayar pajak, maka penunggakan pajak disebabkan petugas kolektor menggunakan untuk kepentingan pribadi. Seperti di desa damai, desa damai adalah salah satu desa dari kecamatan watang sidenreng dengan jumlah penduduk sebanyak 1.486 jiwa dengan mayoritas berprofesi sebagai buruh dan petani.

Berdasarkan dengan apa yang ditemukan bahwa Sekretaris desa damai pada bulan Januari tahun 2020 terdapat kendala yang menyangkut dengan PBB 1) Penagihan pajak hanya berdasarkan SPPT tidak menggunakan SKP karena tidak ada, maka penagihan pajak dilaksanakan secara administratif 2) Adanya petugas kolektor kurang bertanggungjawab mengakibatkan tidak menyetor uang hasil pengumpulan pajak PBB di UPT Pelayanan Pajak Kecamatan Watang Sidenreng. Maka dapat dilihat dari data realisasi penerimaan PBB pada bulan Desember Tahun 2019. Dari data tersebut PBB di desa damai tiga tahun terakhir yakni pada tahun 2017 sampai dengan tahun 2019 target yang diharapkan oleh Dinas Pemerintah Daerah belum terealisasikan dengan sepenuhnya, hal tersebut terjadi dikarenakan pemerintah kurang memperhatikan penanganan atau kurangya tanggung jawab pemerintah dalam melaksanakan pemungutan penerimaan wajib pajak, serta kurang tegasnya pemerintah dalam pelaksanaan pemungutan PBB kepada masyarakat, hal tersebut dapat dilihat turunnya target realisasi PBB di desa damai. Tahun 2017 target penerimaan Pajak 26.670.500 sedangkan yang terealisasi hanya 26.412.288 dengan presentatase 99\% dan berhasil meningkat pada tahun 2018 dengan target 28.750.000 sedangkan yang terealisasi hanya sebanyak 16.950.278 serta presentase 59\%, sedangkan pencapaian target ditahun 2019 dengan target penerimaan PBB 75.581 .677 akan tetapi yang terealisasi penerimaan Pajak Bumi dan Bangunan 49.571.061 presentase 66\%. Maka ini menggambarkan bahwa tingkat akuntabilitas dalam membayar PBB di desa damai saat ini masih sangat rendah. Pajak seharusnya mencapai target yang ditentukan namun tidak sedemikian.

Berdasarkan permasalahan di atas maka peneliti tertarik untuk mengadakan penelitian dengan judul "Akuntabilitas terhadap Pembayaran Pajak Bumi dan Bangunan (PBB) di Desa Damai Kecamatan Watang Sidenreng Kabupaten Sidenreng Rappang". Simbolon (Perwirasari, 2016) mengatakan akuntabilitas adalah 
kewajiban untuk menyampaikan suatu pertanggungjawaban untuk menjawab kinerja atas tindakan seseorang maupun badan hukum/pimpinan kolektif, serta organisasi kepada pihak yang memiliki hak dan wewenang untuk meminta pertanggungjawaban. Jadi, dapat disimpulkan bahwa seseorang yang memiliki kewajiban dapat memberikan suatu pertanggung jawab atas tindakan yang dilakukan orang tersebut, baik di badan hukum maupun organisasi. Akuntabilitas menurut David Hulme dan Mark Turner ( Mukhilda, 2013) sebagai berikut:

1. Keberadaan kualitas moral yang memadai

(Hudi, 2017) Moral adalah ide-ide yang umum diterima tentang tindakan manusia, yang mampu membedakan mana yang baik dan mana yang wajar.

a. Kesadaran Moral (Moral Awareness). Kegagalan moral yang sering terjadi pada diri manusia dalam semua tingkatan usia adalah kebutaan moral kondisi di mana orang tak mampu melihat bahwa situasi yang sedang ia hadapi melibatkan masalah moral dan membutuhkan pertimbangan lebih jauh. Aspek kedua dari kesadaran moral adalah kendala untuk bisa mendapatkan informasi. Dalam penilaian moral, sering kali kita sulit memutuskan yang mana benar sampai kita mengetahui suasana yang sesungguhnya.

b. Pengambilan Perspektif (Perspektive Taking).

Pengambilan perspektif ialah kemampuan dalam mengambil sudut pandang, dilihat dari situasi sudut pandang orang lain, membayangkan bagaimana mereka akan berpikir, bereaksi, dan merasa.

c. Membuat Keputusan (Decision Making). Mampu memikirkan langkah yang mungkin akan diambil seseorang yang sedang menghadapi persoalan moral disebut sebagai keterampilan pengambilan keputusan reflektif.
2. Kepekaan.

(Rohima, 2018) Kepekaan merupakan bagian karakter yang terdapat dalam diri seorang individu untuk mudah terangsang terhadap lingkungannya dan di latih keluar dari perasaan kita sendiri untuk memasuki perasaan orang lain. Adapun macam atau sebutan lain dari kepekaan sosial yaitu:

a. Empati. Empati adalah kemampuan mengenali, atau merasakan, keadaan orang lain. Selain itu empati juga berarti keadaan yang menjadikan kita dalam keadaan perasaan atau pikiran yang sama dengan orang lain.

b. Kepedulian Sosial. Secara sederhana kepekaan yang artinya suatu keadaan seseorang yang mudah merasakan perubahan terhadap hal-hal kecil yang terjadi di sekelilingnya. Seseorang yang mempunyai kepekaan yang sangat tinggi, akan mudah memiliki rasa peduli kepada sesama yang tinggi pula.

3. Keterbukaan

Mustopa Dijaja (Zainuddin, 2017) transparansi adalah keterbukaan pemerintah dalam membuat kebijkankebijakan sehingga dapat diketahui oleh masyarakat. Transparansi pada akhinya akan menciptakan akuntabilitas antara pemerintah dengan rakyat.

Adapun faktor-faktor tingkat kesadaran masyarakat dalam membayar pajak bumi dan bangunan menurut Theory of planned behavior (TPB) (Suaryana, 2019),yaitu:

1. Behaviorial beliefs ialah keyakinan individu terhadap hasil dari suatu perilaku dan evaluasi atas hasil tersebut, yang berkaitan dengan kemauan wajib pajak untuk membayar pajak.

2. Normative beliefs ialah keyakinan terhadap harapan normatif orang lain yang dan motivasi dalam memenuhi harapan harapan tersebut, yang berkaitan dengan kualitas pelayanan yang diharapkan oleh seluruh wajib pajak dapat memberikan pelayanan yang terpercaya, handal, sehingga 
masyarakat akan memiliki pandangan yang positif untuk membayar pajak.

3. Control beliefs ialah keyakinan pada hal-hal yang mendukung atau menghambat perilaku serta persepsinya terhadap seberapa kuat hal-hal tersebut mendukung dan menghambat perilaku (perceived power).

Menurut Siahan (Lubis, 2015) pajak bumi dan bangunan merupakan pajak diatas bangunan yang dimilik, serta dikuasai, kiecuali kawasan digunakan dalam hal kegiatan usaha perkebunan, hutan, serta pertambangan. Menurut (Toly, 2013) indikator pajak bumi dan bangunan yaitu:

1. Mengetahaui fungsi pajak ialah peranan yang cukup signifikan dalam kehidupan berbangsa maupun bernegara, khususnya dalam pembangunan. Pajak yang menjadi sebuah kenyataan dalam kehidupan masyarakat tentunya memiliki fungsi tertentu. (Parsa \& Sumertayasa, 2018).

2. Kesadaran membayar pajak ialah hal yang sangat penting untuk penarikan pajak tersebut, dalam menentukan keberhasilan pungutan pajak dengan suatu kemauan wajib pajak dalam membayar kewajiban pajaknya, berdasarkan upaya yang dilakukan oleh pemerintah baik upaya pendidikan, dan lain-lain. Jika pemerintah tidak melakukan sosialisasi terhadap sistem perpajakan dan mudah dipahami oleh masyarakat terutama para wajib itu sendiri. (Lovihan, 2011)

\section{B. METODE PENELITIAN}

Desain yang digunakan yaitu deskriptif kuantitatif dimana setiap variabel yang ditentukan, diukur dengan memberikan simbol-simbol angka yang berbeda sesuai kategori informasi yang berkaitan dengan variabel-variabel teresebut. Populasi pada penelitian ini, sebanyak 1.486 jiwa yang merupakan penduduk Desa Damai. Jumlah sampel adalah 74 orang/masyarakat. Dengan menggunakan teknik simple random sampling.

\section{HASIL PENELITIAN DAN PEMBAHASAN}

1. Penelitian akuntabilitas (X) a. keberadan kualitas moral. Keberadaan kualitas moral merupakan disini sikap seorang petugas kolektor desa damai yang bersikap ramah pada saat menagih pajak kepada masyarakat sebesar $58,6 \%$.

2. Kepekaan merupakan disini sikap seorang petugas kolektor desa damai dekat dengan masyarakat sebesar $72,8 \%$.

3. Keterbukaan merupakan disini tentang petugas kolektor desa damai memberikan pemahaman tentang pentingnya wajib pajak sebesar $69,6 \%$.

Hasil penelitian pajak bumi dan bangunan ( $Y$ ) a. Mengetahui fungsi pajak yang merupakan disini petugas kolektor desa damai melakukan upaya dalam membangun kesadaran masyarakat tentang pentingnya membayar pajak sebesar $68,2 \%$. b. Kesadaran membayar pajak merupakan disini petugas kolektor desa damai mendorong masyarakat supaya membayar pajak sebesar $72,6 \%$. Hasil penelitian Faktor-faktor yang mempengaruhi tingkat kesadaran dalam membayar pajak a. Keyakinan terhadap hasil yang dimaksud disini masyarakat desa damai mengetahui tata cara membayar pajak sebesar $60,4 \%$. b. Keyakinan terhadap normatif yang dimaksud disini warga desa damai memiliki pandangan positif kepada kolektor desa damai karena kinerjanya yang baik sebesar 58,6\%. c. Keyakinan terhadap hal-hal yang mendukung atau menghambat yang merupakan disini kolektor desa damai yang mampu mempengaruhi masyarakat dalam membayar pajak sebesar $62,8 \%$. Berdasarkan uraian tersebut, maka dapat disimpulkan bahwa faktor-faktor yang mempengaruhi tingkat kesadaran masyarakat dalam membayar pajak bumi dan bangunan di Desa Damai berada pada kategori "baik" dengan presentase $60.6 \%$. 
D. KESIMPULAN

Berdasarkan apa yang telah dipaparkan diatas, maka hal ini dapat disipmpulkan bahwa;

1. Berdasarkan hasil perhitungan SPSS maka, t hitung > tabel atau $3.650>$ 1,993, maka $\mathrm{HO}$ ditolak dan $\mathrm{Ha}$ diterima, artinya Signifikan. Jadi, Akuntabilitas berpengaruh / Signifikan terhadap Pembayaran Pajak Bumi dan Bangunan di Desa Damai Kecamatan Watang Sidenreng Kabupaten Sidenreng Rappang.

2. Hasil penelitian Faktor-Faktor yang mempengaruhi tingkat kesadaran dalam membayar pajak 1) Behavorial beliefs atau keyakinan individu $60,4 \%$. 2) Normative beliefs atau keyakinan terhadap normatif 58,6\%. 3) Control beliefs atau keyakinan hal-hal yang mendukung atau menghambat $62,8 \%$. Berdasarkan dari uraian diatas, maka dapat disimpulkan bahwa faktor-faktor yang mempengaruhi tingkat kesadaran dalam membayar pajak di Desa Damai berada pada kategori baik dengan presentase $60,6 \%$.

\section{E. REFERENSI}

Ahmad, Jamaluddin. (2015). Metode penelitian administrasi publik teori dan aplikasi. Yogyakarta: Gava Media

Hudi, I. (2017). Pengaruh pengetahuan moral terhadap perilaku moral pada siswa smp negeri kota pekan baru berdasarkan pendidikan orangtua, 2(1), 30-44.

Lovihan, S. (2011). Pengaruh kesadaran membayar pajak,pengetahuan dan pemahaman

peraturan perpajakan,dan kualitas layanan terhadap kemauan membayar pajak wajib orang pribadi di kota tomohon,

Lubis, P. K. D. (2015). Analisis penerimaan pajak bumi dan bangunan pada dinas pendapatan daerah kota medan putri,

Mukhilda, N. (2013). Akuntabilitas pelayanan publik ( studi kasus: penyelenggaraan pelayanan izin mendirikan bangunan program studi administrasi negara.

Parsa, I. G. A. P. W. I. W., \& Sumertayasa, P. G. A. (2018). Pengaturan tentang pengenaan pajak bea perolehan hak atas tanah dan bangunan (bphtb) atas hibah,

Perwirasari, F. B. P. (2016). Faktor-faktor yang mempengaruhi akuntabilitas kinerja instansi pemerintah (akip).

Rohima, E. (2018). Upaya meningkatkan kepekaan sosial melalui layanan bimbingan kelompok dengan teknik diskusi di man pematang bandar.

Suaryana, K. A. P. I. G. N. A. (2019). Faktor-Faktor Yang Mempengaruhi Kemauan Membayar Pajak WPOP Di Kantor Pelayanan Pajak.

Toly, C. C. S. dan A. A. (2013). FaktorFaktor yang Mempengaruhi Kepatuhan Wajib Pajak dalam Memenuhi Kewajiban Membayar Pajak di Surabaya, 